\title{
HEALTH PROBLEMS AMONG THE ELDERLY AT MAJALAYA PUBLIC HEALTH CENTERS (PUSKESMAS) WEST JAVA-INDONESIA
}

\author{
Agiesta Sephya Shobarina ${ }^{1}$, Aat Sriati ${ }^{2}$, Iwan Shalahuddin ${ }^{3}$
}

${ }^{1}$ Ners Study Students of Faculty of Nursing Padjadjaran University Bandung, West Java Indonesia

2Lecturer in Faculty of Nursing Padjadjaran University Bandung, West Java Indonesia

${ }^{3}$ Lecturer in Nursing Study Program (Garut Campus) of Padjadjaran University, West Java Indonesia.

Email: shalahuddin@unpad.ac.id

\section{ABSTRACT}

Background: Elderly Health problems can lead to decline in elderly body functions and become a factor that improves health problems. As a result, many elderly people come to public health services every day with the same complaints and different complaints.

Purpose: to recognize the description of health problems among the elderly at Majalaya public health centers (Puskesmas) West Java-Indonesia

Methods: A descriptive research with documentation study. The object of research is medical records of elderly who went to public health center during the last 1 year from April 2017 until March 2018. The number of samples is 3899 elderly based on elderly visit number gained by total sampling technique. The technique of data collection is through elderly medical records at Majalaya Public Health Centre during the last 1 year. This research uses frequency distribution and proportion analysis.

Results: Showed that almost all elderly came independently without being escorted by their families and hypertension was the highest-ranking health problems experienced by elderly $(40,9 \%)$ others were rheumatoid atritis $(14,9 \%)$, cough and flu $(8.2 \%)$, gastritis $(7,9 \%)$ and chepalgia $(7.6 \%)$, they were the 5 th highest health problems experienced by the elderly at Majalaya Public Health center during the last 1 year.

Conclusion: Among 22 health problems that are experienced by elderly, hypertension is the most common problem complained by elderly. It is recommended that health care workers optimize services regarding the handling and treatment of chronic health problems among elderly.

Keywords : Elderly, Health Problems, Independency

\section{INTRODUCTION}

Indonesia is one of the top five countries with the largest number of elderly in the world. The elderly population in Indonesia is increasing in 2014 , amounting to 18,781 people, in 2017 as many as 33.66 million people $(9.03 \%)$. It is estimated that it will continue to increase in 2020 (27.08 million), in 2025 (33.69 million) and in 2035 (48.19 million) (Ministry of Health of the Republic of Indonesia, 2013; Sari, Ningsih, \& Pratiwi, 2018; Muhith, 2015). As we get older, the aging process will result in changes in physiological functions so that non-communicable diseases will be experienced by the elderly. Elderly people are also susceptible to infection due to degenerative problems that reduce the body's resistance from the elderly themselves so that it can cause the elderly to be attacked by infectious diseases and will be characterized by biological deterioration such as sedentary lines on the skin, whitening head hair, decreased sense of vision and hearing, teeth begin to loose and easily experience fatigue
(Dewi, 2015; Luthfiyati, \& Ceria, 2017; Setiyorini, Wulandari, \& Sari, 2018).

In 2015 the number of elderly morbidities was $28.62 \%$, which means that every 100 elderly people there were about 28 people who experienced illness. Based on the type of region, the elderly who live in urban health status tend to be better than the elderly who live in rural areas. (Central Bureau of Statistics, 2015; Rohmawati, 2013; Rohaedi, Putri, \& Kharimah, 2016).

Older people are a group of people who are over 60 years old. Elderly people will experience a decrease and even a loss of tissue ability to replace and maintain normal functions that slowly cause the elderly will not be resistant to infection and repair the damage that occurs. Therefore in the elderly body there will be a buildup of metabolic and structural distortions which are referred to as degenerative diseases that cause these elderly people to eventually end up living with terminal diseases (Triwanti, Ishartono, \& Gutama, 2015; Sholikhah, 2017; Mokoginta, 2014). To find out the 
Malahayati International Journal of Nursing and Health Science, Volume 02, No.1, March 2019: 6-13 HEALTH PROBLEMS AMONG THE ELDERLY AT MAJALAYA PUBLIC HEALTH CENTERS (PUSKESMAS) WEST JAVA-INDONESIA

problems that occur in the elderly, in February (2018) researchers looked for authentic data about health problems experienced by the elderly in the Majalaya area to the closest health institutions such as the Puskesmas. Because of the large number of elderly people who have decreased physical function and experience various kinds of diseases and various kinds of complaints in themselves, this needs to be done.

\section{RESEARCH METHODS}

This study was a descriptive study with a documentation study design. In this study, the type of descriptive research with documentation study design was used to provide an overview of health problems in the elderly at Majalaya Health Center. The population in this study was the number of elderly who treated for the past 1 year from April
2017 to March 2018 by going to the Majalaya Health Center based on documentation studies totaling 3899 elderly people based on the number of elderly visits. In this study using sample techniques in total population because the samples taken include the whole population element which means the number of samples is equal to the population. Data was taken with a documentation study guideline instrument based on records of elderly visits in the Majalaya health center based on the characteristics of the elderly, type of visit, health problems experienced by the elderly.

\section{RESEARCH RESULTS}

The results of the study on Elderly Health Problems Based on the Number of Visits in the Majalaya Health Center, are presented in tabulation form the following tables:

Table 1. Distribution of Frequency of Elderly Characteristics

\begin{tabular}{lll}
\hline Variable & Frequency & Percentage \\
\hline Age & & \\
60-79year & 3705 & 95 \\
80-94year & 196 & 5 \\
Gender & & \\
Male - Male & 1595 & 40.9 \\
Female & 2304 & 59.1 \\
Types of Patient & & \\
New & 314 & 8.1 \\
Old & 3585 & 91.9 \\
Independence & & \\
squire & 16 & 0.4 \\
sometimes & 39 & 1,4 \\
not delivered & 3844 & 98.6 \\
Counseling & & \\
New & 314 & 8.1 \\
Long & 3585 & 91.9 \\
Actions given & & \\
Referred & 8 & 0.2 \\
Treated & 3891 & 99.8 \\
\hline
\end{tabular}

Based on table 1 it can be concluded from the type of visit that the elderly often come repeatedly to the Majalaya Health Center for the past 1 year (April 2017 - March 2018). The number of elderly visits is dominated by elderly women as many as 2304 visits $(59.1 \%)$ in the age range of $60-79$ years $(95 \%)$. Viewed from the aspect of independence, most of the elderly came independently to the Majalaya Health Center without being escorted by their families or siblings. Elderly people who come will be given counseling and almost all the elderly who seek treatment are directly handled by health care officers in the Majalaya health center $(99.8 \%)$.

Agiesta Sephya Shobarina' Ners Study Students of Faculty of Nursing Padjadjaran University Bandung, West Java Indonesia

Aat Sriati ${ }^{2}$ Lecturer in Faculty of Nursing Padjadjaran University Bandung, Indonesia

Iwan Shalahuddin ${ }^{3}$ Lecturer in Nursing Study Program (Garut Campus) of Padjadjaran University, West Java Indonesia.

Email: shalahuddin@unpad.ac.id 
Malahayati International Journal of Nursing and Health Science, Volume 02, No.1, March 2019: 6-13 HEALTH PROBLEMS AMONG THE ELDERLY AT MAJALAYA PUBLIC HEALTH CENTERS (PUSKESMAS) WEST JAVA-INDONESIA

Table 2. Frequency Distribution Based Health Problems

\begin{tabular}{lcc}
\hline Variable & Frequency & Percentage \\
\hline Cardiovascular & 1596 & 40.9 \\
Hypertension & 21 & 0.5 \\
$\begin{array}{l}\text { Hypotension } \\
\text { Neurology }\end{array}$ & & \\
Chepalgia & 296 & 7.6 \\
Stroke & 10 & 0,3 \\
Musculoskeletal & & \\
Rheumatism & 581 & 14.9 \\
Myalgia & 16 & 0.4 \\
Digestion & & \\
Diarrhea & 82 & 2.1 \\
Gastritis & 309 & 7.9 \\
Hemorrhoidal & 13 & 0,3 \\
Urinary & & \\
UTI & 67 & 1.7 \\
Endocrine & & \\
Diabetes Mellitus & 100 & 2.6 \\
Respiratory & & \\
TB & 8 & 0,2 \\
Pharyngitis & 26 & 0.7 \\
ISPA & 102 & 2.6 \\
Sensing & & \\
OMA \\
Conjunctivitis \\
Integumentary
\end{tabular}

Based on table 2 shows the health problems experienced by the elderly, including disorders of the cardiovascular system, namely hypertension is a health problem most suffered by the elderly $(40.9 \%)$, besides that the most experienced disease is the musculoskeletal system, one of which is rheumatism $(14,9 \%)$ along with the symptoms of the disease that most often affects the elderly is flu cough $(8.2 \%)$ disorders of the digestive system such as gastritis $(7.9 \%)$ and chepalgia $(7.6 \%)$. The five diseases are the highest order diseases suffered by the elderly in the Majalaya health center based on the number of visits, while the lowest percentage of diseases is pulmonary TB $(0.2 \%)$. This data was obtained from documentation of records of visits of the elderly during the past 1 year at the Majalaya Health Center.

\section{DISCUSSION}

Based on the results of the study showing that in the last 1 year (April 2017 - March 2018) many elderly people visited repeatedly to the Majalaya Health Center, this was caused by a decrease in various body functions in the elderly so that many elderly people felt various complaints. Every day,

Agiesta Sephya Shobarina' Ners Study Students of Faculty of Nursing Padjadjaran University Bandung, West Java Indonesia

Aat Sriati ${ }^{2}$ Lecturer in Faculty of Nursing Padjadjaran University Bandung, Indonesia

Iwan Shalahuddin ${ }^{3}$ Lecturer in Nursing Study Program (Garut Campus) of Padjadjaran University, West Java Indonesia.

Email: shalahuddin@unpad.ac.id 
Malahayati International journal of Nursing and Health Science, Volume 02, No.1, March 2019: 6-13 HEALTH PROBLEMS AMONG THE ELDERLY AT MAJALAYA PUBLIC HEALTH CENTERS (PUSKESMAS) WEST JAVA-INDONESIA

many elderly people come to the puskesmas to seek medical treatment and check their health, as the results of research in documents are noted that many of them come independently without being sent by their families or siblings and are independent to carry out their daily activities. Previous research was closely related to showing more than half of the elderly experienced dependency in carrying out daily activities caused by being unable and unable to carry out activities optimally (Lestari, Wihastuti, \& Rahayu, 2013; Chintyawati, 2014; Supriani, 2011; Ahdaniar, Hasanuddin, \& Indar, 2014).

Some elderly diseases who went to the Majalaya health center for the past 1 year suffered from many chronic diseases such as hypertension, chepalgia, rheumatism, cough flu, gastritis and other chronic diseases. The results of this study are possible because the elderly experience a loss of tissue ability to maintain normal function and a decrease in immune system making the elderly tend to be attacked by diseases or infections.

Other studies that are closely related to our research by stating the complaints felt by the elderly are the effects of chronic diseases suffered and the most are hypertension with an age range of 65 years and above (Widodo, \& Sumardino, 2016; Azizah, Azizah, \& Dwi Hartanti , 2016; Yuniarti, 2011; Rosyiani, Sudaryanto, \& Listyorini, 2015). This can be caused because the elderly are included in the group that is susceptible to various diseases due to the inability to work tissue functions in the body and decreased function (Dupouy, Moulis, Tubery, Ecoiffier, Sommet, Poutrain, \& Lapeyre-Mestre, 2013; Rutecki, \& Yates 2018; Rantz, Skubic, Popescu, Galambos, Koopman, Alexander, \& Miller, 2015).Previous research that is closely related is that chronic disease is a disease that cannot heal completely and requires considerable time. Patients with chronic diseases usually affect the economy of individuals, families and communities. Chronic disease will cause a decrease in quality of life in the elderly because it results in biopsychosocial disorders that will limit the activity of the elderly (Satrianegara, 2014; Swasono, 2015; Rahayu, 2014; Willmott, 2014).

From the results of the study, it was found that out of 22 health problems experienced by the elderly, cardiovascular diseases, namely hypertension, became the most common health problem for the elderly $(40.9 \%)$ and the number was dominated by elderly women of $65-79$ years. This can occur because with increasing age the body will experience a decrease in the elasticity of the blood vessels that will automatically increase blood pressure, a decrease in body function that occurs in the elderly will affect the lack of physical activity of the elderly which can increase the risk of high blood pressure because the heart rate tends to faster and the heart muscle must work harder which causes the elderly to experience high blood pressure. Hypertension in women over the age of 50 is caused by hormonal changes after menopause, and the population of elderly women from 2012 has increased by $10,046,073$ million or more than men who numbered $8,538,832$ million (Republic of Indonesia Ministry of Health Indonesia, 2016; Tallutondok, Lanawati, Sihombing, Tahulending, Tjakrapawira, Samaria, \& Suganthi, 2018; Agustia, Sabrian, \& Woferst, 2014).

Previous research has determined that hypertension tends to occur in the elderly with the category of being in old age (Novitaningtyas, 2014; Rosta, 2011; Anggraini, 2014). The high level of hypertension is in line with increasing age in the elderly caused by changes in the structure of blood vessels that become narrower and the walls stiff, which results in increased systolic blood pressure (Rahajeng, \& Tuminah, 2009; Ariani, 2013; Marhani, 2014).

The subjects in the study who had a lot of hypertension were women, on average women who had menopause at 45 years of age would be at increased risk of high blood pressure, if women who were not menopausal were affected by the hormone estrogen which plays a role in increasing HDL levels in the body (Handajani, et al., 2010; Ministry of Health of the Republic of Indonesia, 2013; Widyaningrum, 2012). Unlike the case with previous research which states that one is at risk of chronic disease, one of them is hypertension in those who are aged 50 years and over, caused by ignorance of the elderly in using treatment therapy well and the elderly do not know the management of hypertension (Allen, et al, 2013 ; Asekun, et al, 2013; Garrison, et al., 2017).

Agiesta Sephya Shobarina' Ners Study Students of Faculty of Nursing Padjadjaran University Bandung, West Java Indonesia

Aat Sriati ${ }^{2}$ Lecturer in Faculty of Nursing Padjadjaran University Bandung, Indonesia

Iwan Shalahuddin ${ }^{3}$ Lecturer in Nursing Study Program (Garut Campus) of Padjadjaran University, West Java Indonesia. Email: shalahuddin@unpad.ac.id 
The results showed that 4418 Japanese people aged 65-85 years had hypertension, did not get antihypertensive drugs for a long period of time, this could result in many elderly people being attacked by the disease stroke, heart and blood vessel disease and kidney failure (43\%). Psychological aspects are things that play an important role in the physical and spiritual health of the elderly. In several studies showed the results that many elderly people who experience psychological disorders one of them is depression. The results of previous studies were closely related that the majority of the elderly had moderate depression related to the level of social interaction. This can be caused because the elderly feel lonely (Kusumowardani, \& Puspitosari, 2014; Wulansari, 2015; Lubis, 2018). Other studies say that the majority of the elderly experience mild depression. This is because the elderly experience a lot of decline in body function so that they have limitations in carrying out daily activities (Astuti, 2010; Sutinah, \& Maulani, 2017; Wulandari, \& Rahayu, 2011).

Research conducted at the Majalaya Community Health Center has not been able to determine the level of psychological disorders in the elderly who came for treatment because the document records the visit of the elderly regarding psychological disorders not complete / not filled by health care workers.

Various kinds of health problems experienced by these elderly people both from physical and psychological aspects, then proper handling is needed, one of which is the importance of the role of nurses in carrying out promotive, preventive, curative and rehabilitative efforts.

Promotive is an action taken to prevent a disease and improve health status which is done directly or indirectly. Based on the results of interviews with health care workers in the Majalaya Health Center, one of the promotive forms carried out was the active activities of Posbindu in each village in the work area of the Majalaya Health Center.

These activities included health counseling, elderly gymnastics, hypertension exercise, blood pressure control and blood sugar checks and monitoring the nutritional status of the elderly who came to Posbindu. In addition to nurses, village cadres also have an important role, in this case cadres will direct the elderly to check their health to the Posbindu in the working area of the puskesmas. Cadres around the work area of the Majalaya
Community Health Center have played an active role in the sustainability of the Posbindu, this is evidenced by the number of elderly people who come to Posbindu in 5 villages and the Posbindu can go on schedule.

Unlike the case with previous studies which showed that the diseases most suffered by the elderly were hypertension, joint disease, anemia, cataracts and other degenerative diseases. In an effort to improve the welfare and health of the elderly then organized health care plan that is heading development of integrated (Armiyati, et al, 2010; Wahyuni, et al, 2016; Mawaddah, et al, 2018; Rusmin, et al, 2017).

Implementation Posbindu Village The water spinach has not run well and maximally, this is due to a lack of cadres because most people feel less confident in providing health services to the elderly in Posbindu. Besides that, nurses from Mranggen Health Center were also felt to be very lacking due to the limited human resources available to deal with the posbindu problems that exist in the working area of the puskesmas.

\section{CONCLUSION}

Based on the results of the research and discussion, it can be concluded that: The results showed that the elderly who came to the Puskesmas had a fairly good level of independence, because almost all came independently and were not delivered by their families or siblings.

Based on health problems, hypertension is the most common health problem for the elderly and the least number of diseases is pulmonary tuberculosis, seen from psychological disorders, in the Majalaya Community Health Center, the level of psychological disturbances in the elderly due to documented records of elderly visits regarding disorders psychology is not filled by health care workers.

\section{SUGGESTIONS}

Health care workers, especially elderly program officers are expected to further optimize and complete the documentation for visits of elderly people who seek treatment at health centers, make routine activities outside the puskesmas such as elderly gymnastics or hypertension exercises for the elderly who are open to the public, make posters in patient service or in the waiting room that deals with the elderly, as well as completing data on the social and

Agiesta Sephya Shobarina' Ners Study Students of Faculty of Nursing Padjadjaran University Bandung, West Java Indonesia

Aat Sriati ${ }^{2}$ Lecturer in Faculty of Nursing Padjadjaran University Bandung, Indonesia

Iwan Shalahuddin ${ }^{3}$ Lecturer in Nursing Study Program (Garut Campus) of Padjadjaran University, West Java Indonesia. Email: shalahuddin@unpad.ac.id 


\begin{abstract}
Malahayati International Journal of Nursing and Health Science, Volume 02, No.1, March 2019: 6-13 HEALTH PROBLEMS AMONG THE ELDERLY AT MAJALAYA PUBLIC HEALTH CENTERS (PUSKESMAS) WEST JAVA-INDONESIA
\end{abstract}

economic status of the elderly who come for

\section{REFERENCES}

Agustia, S., Sabrian, F., \& Woferst, R. (2014). Hubungan gaya hidup dengan Fungsi kognitif pada lansia. Jurnal Program Studi IImu Keperawatan Universitas Riau, 1-8.

Ahdaniar, A., Hasanuddin, H., \& Indar, I. (2014). Faktor yang berhubungan dengan kejadian penyakit rematik pada lansia di wilayah puskesmas kassi-kassi kota Makassar. Jurnal IImiah kesehatan diagnosis, 4(2), 150-156.

Allen, M., Kelly, K., \& Fleming, I. (2013). Hypertension in elderly patients: recommended systolic targets are not evidence based. Canadian family physician, 59(1), 19-21.

Angraini, R. D. (2014). Hubungan Indeks Massa Tubuh (IMT), Aktivitas Fisik, Rokok, Konsumsi Buah, Sayur Dan Kejadian Hipertensi Pada Lansia Di Pulau Kalimantan (Analisis Data Riskesdas 2007). Hubungan indeks massa tubuh (IMT), aktivitas fisik, rokok, konsumsi buah, sayur dan kejadian hipertensi pada lansia di pulau kalimantan (Analisis Data Riskesdas 2007).

Ariani, A. D. (2013). Hipertensi grade ii dengan prediabetes pada pasien laki-laki lanjut usia. Jurnal Medula, 1(01), 19-28.

Armiyati, Y., Soesanto, E., \& Hartiti, T. (2014). Pemberdayaan Kader Posbindu Lansia Sebagai Upaya Peningkatan Kualitas Hidup Lansia di Desa Kangkung Demak. In Prosiding Seminar Nasional \& Internasional.

Asekun-Olarinmoye, E. O., Akinwusi, P. O., Adebimpe, W. O., Isawumi, M. A., Hassan, M. B., Olowe, O. A., ... \& Adewole, T. A. (2013). Prevalence of hypertension in the rural adult population of Osun State, southwestern Nigeria. International journal of general medicine, 6, 317.

Astuti, V. W. (2012). Hubungan dukungan keluarga dengan tingkat depresi pada lansia Di Posyandu Sejahtera GBI Setia Bakti Kediri. Jurnal Penelitian STIKES Kediri, 3(2), 85-93. treatment.

Azizah, R., \& Dwi Hartanti, R. (2016). Hubungan Antara Tingkat Stress Dengan Kualitas Hidup Lansia Hipertensi Di Wilayah Kerja Puskesmas Wonopringgo Pekalongan.

Badan Pusat Statistik. (2015). Central Statistics Agency. Survei sosial ekonomi nasional (SUSENAS)[National Social and Economic Survey] Unpublished dataset.

Chintyawati, C. (2014). Hubungan antara nyeri Reumatoid Artritis dengan kemandirian dalam aktivitas kehidupan sehari-hari pada lansia di Posbindu Karang Mekar wilayah kerja Puskesmas Pisangan Tangerang Selatan.

Culo, S. (2011). Risk assessment and intervention for vulnerable older adults. BC Med J, 53(8), 421425.

Departemen Kesehatan Republik Indonesia. (2013). Riset kesehatan dasar (Riskesdas) 2013.

Dewi, S. R., (2015). Buku ajar keperawatan gerontik. Deepublish.

Dupouy, J., Moulis, G., Tubery, M., Ecoiffier, M., Sommet, A., Poutrain, J. C., \& Lapeyre-Mestre, M. (2013). Which adverse events are related to health care during hospitalization in elderly inpatients?. International journal of medical sciences, 10(9), 1224.

Garrison, S. R., Kolber, M. R., Korownyk, C. S., McCracken, R. K., Heran, B. S., \& Allan, G. M. (2017). Blood pressure targets for hypertension in older adults. Cochrane Database of Systematic Reviews, (8).

Handajani, A., Roosihermatie, B., \& Maryani, H. (2010). Faktor-faktor yang berhubungan dengan pola kematian pada penyakit degeneratif di Indonesia. Buletin penelitian sistem kesehatan, 13(1).

Kementrian Kesehatan Republik Indonesia. (2016). Situasi Lanjut Usia (Lansia) di Indonesia: 29 MeiHari Lanjut Usia Nasional. Info DATIN Pusat Data dan Indormasi Kementrian Kesehattan RI. ISSN, 2442-7659

Agiesta Sephya Shobarina' Ners Study Students of Faculty of Nursing Padjadjaran University Bandung, West Java Indonesia

Aat Sriati ${ }^{2}$ Lecturer in Faculty of Nursing Padjadjaran University Bandung, Indonesia

Iwan Shalahuddin ${ }^{3}$ Lecturer in Nursing Study Program (Garut Campus) of Padjadjaran University, West Java Indonesia. Email: shalahuddin@unpad.ac.id 
Kementrian Kesehatan Republik Indonesia. (2013). Gambaran kesehatan lanjut usia di Indonesia. Jakarta: Kemenkes RI.

Kusumowardani, A., \& Puspitosari, A. (2014). Hubungan Antara Tingkat Depresi Lansia Dengan Interaksi Sosial Lansia Di Desa Sobokerto Kecamatan Ngemplak Boyolali. Interest: Jurnal IImu Kesehatan, 3(2).

Lestari, R., Wihastuti, T. A., \& Rahayu, B. F. (2013). Hubungan tingkat kecemasan dengan tingkat kemandirian Activities of Daily Living (ADL) pada lanjut usia di panti werdha. Jurnal IImu Keperawatan, 1(2), 128-134.

Lubis, A. F. (2018). Hubungan Tingkat Depresi dengan Interaksi Sosial pada Lansia di Desa Sena Kecamatan Batang Kuis Kabupaten Deli Serdang.

Luthfiyati, Y., \& Ceria, I. (2017). Faktor penentu kunjungan lansia ke posyandu lansia di dusun Cokrobedog desa Sidoarum Sleman. Jurnal Kesehatan Ibu dan Anak Akademi Kebidanan An-Nur, 2(2).

Marhani, R. S. (2014). Hypertension grade II in elderly men with a family approach. Jurnal Medula, 3(01), 91-97.

Mawaddah, N., Syurandhari, D. H., \& Basahi, H. (2018). Optimalisasi posyandu lansia sebagai upaya peningkatan partisipasi dan kualitas hidup lansia. Medica majapahit, 10(2), 100-110.

Mokoginta, S. H. O. M. (2014). Gambaran stressor dan mekanisme koping pada lansia sebelum masa pensiun di Kecamatan Kotamobagu Utara Kota Kotamobagu (Doctoral dissertation, Universitas Negeri Gorontalo).

Muhith, A. (2015). Kemampuan Fungsional Lansia Di UPT Panti Werdha "Majapahit" Mojokerto. Hospital Majapahit, 2(2).

Novitaningtyas, T. (2014). Hubungan karakteristik (umur, jenis kelamin, tingkat pendidikan) dan aktivitas fisik dengan tekanan darah pada lansia di Kelurahan Makamhaji Kecamatan Kartasura Kabupaten Sukoharjo (Doctoral dissertation, Universitas Muhammadiyah Surakarta)

Rahajeng, E., \& Tuminah, S. (2009). Prevalensi hipertensi dan determinannya di Indonesia. Majalah Kedokteran Indonesia, 59(12), 580-587.

Rahayu, T. (2014). Hubungan Antara Dukungan Sosial Dengan Kesejahteraan Psikologis Pada Penderita Diabetes Mellitus Tipe 2 (Doctoral dissertation, Universitas Muhammadiyah Surakarta).

Rantz, M. J., Skubic, M., Popescu, M., Galambos, C., Koopman, R. J., Alexander, G. L., \& Miller, S. J. (2015). A New Paradigm of TechnologyEnabled 'Vital Signs' for Early Detection of Health Change for Older Adults. Gerontology, 61(3), 281-290.

Rohaedi, S., Putri, S. T., \& Kharimah, A. D. (2016). Tingkat kemandirian lansia dalam activities daily livingdi panti sosial tresna werdha senja rawi. Jurnal Pendidikan Keperawatan Indonesia, 2(1), 16-21.

Rohmawati, N. (2013). Anxiety, Asupan Makan, dan Status Gizi Pada Lansia di Kabupaten Jember.

Rosta, J. (2011). Hubungan Asupan Energi, Protein, Lemak dengan Status Gizi dan Tekanan Darah Geriatri di Panti Wreda Surakarta (Doctoral dissertation, Universitas Muhammadiyah Surakarta).

Rosyiani, Y. E. T., Sudaryanto, A., \& Listyorini, D. (2015). Gambaran Kualitas Hidup Lanjut Usia Yang Mengalami Sakit Asam Urat (Gout) Di Posyandu Lanjut Usia Desa Pelemgadung Karangmalang Sragen (Doctoral dissertation, Universitas Muhammadiyah Surakarta).

Rusmin, M., Bujawati, E., \& Baso, N. H. (2017). Faktor-Faktor yang Berhubungan Dengan Pemanfaatan Posyandu Lansia di Wilayah Kerja Puskesmas Somba Opu Kabupaten Gowa Tahun 2015. Al-sihah: The Public Health Science Journal, 9(1).

Agiesta Sephya Shobarina' Ners Study Students of Faculty of Nursing Padjadjaran University Bandung, West Java Indonesia

Aat Sriati ${ }^{2}$ Lecturer in Faculty of Nursing Padjadjaran University Bandung, Indonesia

lwan Shalahuddin ${ }^{3}$ Lecturer in Nursing Study Program (Garut Campus) of Padjadjaran University, West Java Indonesia.

Email: shalahuddin@unpad.ac.id 
Rutecki, G. W., \& Yates JR, F. D. (2018). Decisional Capacity and Suspected SelfNeglect in a Geriatric Patient. Ethics \& Medicine, 34(3), 147-131.

Sari, C. W. M., Ningsih, E. F., \& Pratiwi, S. H. (2018). Description of dementia in the elderly status in the work area health center Ibrahim Adjie Bandung. Indonesian Contemporary Nursing Journal (ICON Journal), 3(1), 1-11.

Satrianegara, M. F. (2014). Pengaruh Religiusitas Terhadap Tingkat Depresi, Kecemasan, Stres, Dan Kualitas Hidup Penderita Penyakit Kronis Di Kota Makassar (Kajian Survei Epidemiologi Berbasis Integrasi Islam Dan Kesehatan). Jurnal Kesehatan, 7(1).

Setiyorini, E., Wulandari, N. A., \& Sari, Y. K. (2018). Upaya untuk meningkatkan kualitas hidup lansia melalui perlahat (persatuan lansia ingin hidup sehat) di desa Jatidowo Kecamatan Rejotangan Kabupaten Tulungagung. Community Development Journal, 2(2), 354-366.

Sholikhah, M. A. (2017). Karakteristik kejadian diabetes mellitus tipe II pada lansia di wilayah kerja Puskesmas Jatilawang (Doctoral Dissertation, Universitas Muhammadiyah Purwokerto).

Supriani, A. (2011). Tingkat depresi pada lansia ditinjau dari tipe kepribadian dan dukungan sosial (Doctoral dissertation, UNS (Sebelas Maret University)).

Sutinah, S., \& Maulani, M. (2017). Hubungan pendidikan, jenis kelamin dan status perkawinan dengan depresi pada lansia. Jurnal Endurance: Kajian IImiah Problema Kesehatan, 2(2), 209-216.

Swasono, M. A. (2015). Hubungan Antara Tingkat Religiusitas Dengan Tingkat Stres Pada Lansia Di Panti Wredha Dharma Bhakti Surakarta (Doctoral dissertation, Universitas Muhammadiyah Surakarta).
Tallutondok, E. B., Lanawati, S., Sihombing, R. M., Tahulending, P., Tjakrapawira, D., Samaria, D., \& Suganthi, J. (2018). Inovasi Media Komunikasi Reminiscence Optimalkan Fungsi Kognitif Lansia Sehat. Prosiding PKM-CSR, 1, 761-773.

Triwanti, S. P., Ishartono, I., \& Gutama, A. S. (2015). Peran Panti Sosial Tresna Werdha dalam Upaya Meningkatkan Kesejahteraan Lansia. Prosiding Penelitian dan Pengabdian kepada Masyarakat, 2(3).

Wahyuni, I. D. W. D., Ainy, A., \& Rahmiwati, A. (2016). Analisis Partisipasi Lansia Dalam Kegiatan Pembinaan Kesehatan Lansia Di Wilayah Kerja Puskesmas Sekar Jaya Kabupaten Ogan Komering Ulu. Jurnal IImu Kesehatan Masyarakat, 7(2).

Widodo, W., \& Sumardino, S. (2016). Pemberdayaan kemampuan lansia dalam deteksi dini penyakit degeneratif. Interest: Jurnal IImu Kesehatan, 5(2).

Widyaningrum, S. (2012). Hubungan antara konsumsi makanan dengan kejadian hipertensi pada lansia.

Willmott, T. (2014). Throughout the Generations: How Age and Religiosity May Be Changing Our Views on Key Social Issues.

Wulandari, A. F. S., \& Rahayu, R. A. (2011). Kejadian dan tingkat depresi pada lanjut usia: studi perbandingan di panti wreda dan komunitas (Doctoral dissertation, Faculty of Medicine).

Wulansarl, I. Y. (2015). Hubungan Antara Gangguan Kognitif Dengan Depresi pada Lanjut Usia Demensia di Posyandu Lansia (Doctoral dissertation, Universitas Muhammadiyah Surakarta).

Yuniarti, A. (2011). Nutritional Status Related To Quality Of Life Of Elderly People In Rappokalling Makassar. Diss. Hasanuddin University.

Agiesta Sephya Shobarina' Ners Study Students of Faculty of Nursing Padjadjaran University Bandung, West Java Indonesia

Aat Sriati ${ }^{2}$ Lecturer in Faculty of Nursing Padjadjaran University Bandung, Indonesia

lwan Shalahuddin ${ }^{3}$ Lecturer in Nursing Study Program (Garut Campus) of Padjadjaran University, West Java Indonesia.

Email: shalahuddin@unpad.ac.id 